\title{
Random Regression Model for Genetic Analysis Milk Traits Holstein Friesian Cow
}

\section{Snežana Trivunović ${ }^{1 *}$, Miroslav Plavšić ${ }^{2}$ and Denis Kučević ${ }^{3}$}

${ }^{1}$ Professor, Breeding, Reproduction and Biotechnology of Animals, Faculty of Agriculture, Novi Sad, Serbia

${ }^{2}$ Professor, President of the Commission, Livestock Farming, Faculty of Agriculture, Novi Sad, Serbia

${ }^{3}$ Associate Professor, Member of the Commission, Livestock Farming Faculty of Agriculture, Novi Sad, Serbia

*Corresponding Author: Snežana Trivunović, Professor, Breeding, Reproduction and Biotechnology of Animals, Faculty of Agriculture, Novi Sad, Serbia.

Received: April 26, 2019; Published: September 30, 2019

DOI: 10.31080/ASAG.2019.03.0671

\section{Abstract}

Genetic analysis of milk traits using the random regression model was performed on the basis of data from completed lactations of Holstein-Friesian cows in Vojvodina in the period from 2011 to 2016. The effect of fixed factors (breed, year of calving, calving season, lactation in order and age) were tested using the GLM in Statica 13.0. Quantitative genetic analysis of data was performed in the WOMBAT software. The average milk yield in standard lactation of $6916.51 \mathrm{~kg}$, with an average fat content $3.80 \%$ and proteins content $3.21 \%$, indicate that milk yield in the examined population is lower than the genetic potential of the breed. All factors showed a statistically significant effect on the observed traits. The heritability of the milk yield ranged from 0.041 to 0.419 , for fat content from 0.389 to 0.490 , proteins content from 0.323 to 0.393 and increased with increasing age in all of the tested traits.

Keywords: Random Regression Model; Milk Traits; Genetic Parameters

\section{Introduction}

Milk cattle, due to their high quality products, are one of the most studied types of domestic mammals. The cultivation accent is on milk production. When it comes to this direction of production, we can say that the Holstein-Friesian race is the most appropriate race on a global scale. By breeding, selection and quality keeping of this race, high production of milk, milk fat and proteins is achieved, which have the greatest impact on revenue. It is believed that the breeding of dairy cattle belongs to the most intensive form of production. Due to the increased need for these products (milk, fat, protein), attention is paid to the precision of selection, that is, to the improvement of the education of high quality throats, which should ensure the production of high quality products.

The breeding goal for the Holstein-Friesian (HF) race is to achieve maximum genetic values for economically important traits, and in line with the economic effects of genetic improvement that this race has achieved in developed countries of the world. For the purpose of achieving the goal of the breeding, it is necessary to select and implement the appropriate selection program.

This implies the selection of the next-generation parents, with the application of genetic assessments and ranking of breeding throats. Different countries use different mathematical-statistical methods for assessing breeding values due to specific geographical and economic conditions. In most developed countries, the Animal Model is applied, of which the Test Day Model is most commonly used. When designing breeding programs for dairy breeds, it is nec- essary to pay attention to the selection of elite parents whose mating is given to the male calves for the progeny tests. It is necessary to mention that this branch of production is one of the leading in the application of advanced techniques such as artificial insemination, embryo transfer and cloning, of which artificial insemination is the most important [1]. Artificial Insemination is a zootechnical method by which an expert person, by applying adequate sources, inserts the sperm dose into the appropriate part of the female full tract at optimum time, during the duration of the estrus, in order to establish normal gravidity. This is very important from the point of view of the selection effect, as with the increase in the number of offspring per breeder that can be tested affects the increase in the intensity of the selection, and therefore the increase in the effect of selection. According to some authors, the organization of artificial insemination and the probe test directly contribute to the improvement and economic progress of production [2].

When it comes to our country, especially in Vojvodina, HolsteinFriesian race is the pillar of milk production [3]. According to the results of the Expert Report [4,5], a large number of cattle breeds of HF race, all categories, in controlled seas from 2012 to 2017, recorded a steady and significant increase. In 2013, compared to 2012 , the total number of cattle in controlled mammals increased by $7.65 \%$ and amounted to 92.051 heads. The growth trend of the number of throats continued in the period from 2014 to 2017 , reaching the number of 125,644 heads, which represents the maximum for the observed period. 


\begin{tabular}{|l|c|c|c|c|}
\hline \multicolumn{1}{|c|}{ Country } & Number The lactation & Milk per cow and 305 (kg) & Dairy Fat (\%) & Protein content (\%) \\
\hline Denmark & 4.475 & - & 4,25 & 3,44 \\
\hline Germany & 161.655 & 8.583 & 4,17 & 3,44 \\
\hline Switzerland & 73.040 & 8.122 & 4,04 & 3,26 \\
\hline France & 1.647 .706 & 9.129 & 3,87 & 3,28 \\
\hline Hungary & 131.599 & 9.685 & 3,67 & 3,29 \\
\hline Austria & 35.944 & 8.809 & 4,07 & 3,29 \\
\hline Serbia & 23.498 & 7.125 & 3,74 & 3,19 \\
\hline Slovenia & 34.094 & 7.839 & 3,97 & 3,28 \\
\hline V.B. & 42.878 & 8.264 & 3,92 & 3,19 \\
\hline
\end{tabular}

Table 1: Overview of the characteristics of the Holstein-Frisian race in 2016 Year. Source: [6].

\section{Holiday-fries race}

The Holstein-Friesian race is today the most colorful race in the world. It is distinguished by a strong constitution with a solid structure with well-attached anime. Race has pronounced dimensions for the depth, height, and length of the body (according to the characteristics of dairy races), and certain parts of the body and their relationships are consistent, so that the throats are an invariant circuit. The dominant color of this race is black and white, although red pops appear in populations where the red gene is recessive. Race is worse for fattening cattle. The average weight of the adult throat is $650-700 \mathrm{~kg}$. They require a high voluminous amount of compound feed and require good housing in addition to food because they are sensitive and susceptible to diseases and infertility if optimal conditions are not provided. The most common problem in production is the low content of milk fat and protein in milk, then postpartum complications.

\section{Genetic variability the nature of literature}

The manifestation of milk properties, as quantitative traits, is influenced by a large number of minor genes. Genetic variability arises as a result of the different actions of the genes and their interactions. The overall variability caused by these genes can be viewed through three major components: additive genetic variance (Va), domination variance (Vd) and residual variance (Ve), (epistatic variance). The epistatic effect of genes can be difficult to distinguish from other actions, while the effect of dominance is perceived through the appearance of heterosis effects and inbreeding. Domination occurs as a result of the interaction of genes located on the same locus. The additive effect is the most important form of gene expression. The sum of all additive effects affecting the property is the average breeding value of the individual.

\section{Genetic parameters of the military properties}

Genetic improvement of quantitative traits in a particular population largely depends on their genetic variability, which can be estimated based on the calculation of the variation components and the coefficient of heritability. Estimates of additive and nonadditive variance components help us to better understand genetic mechanisms [7]. In most statistical models for assessing genetic parameters, it is understood that variances between groups are homogeneous [8], which is a rare case. In recent decades, the assessment methods have been significantly improved genetic variance, primarily because of the ability to use large databases, which significantly improved the accuracy of the test [9]. In addition, it is necessary to mention covariates and correlations that show that genetic changes of one characteristic affect other characteristics in a given breeding target, and if the selection is performed for repetitive properties and measures repeatedly throughout life, the relationship between the components of the variance shows us repitability.

\section{Milk characteristics variant components}

The variance represents the expected mathematical deviation of the random variable from its mean value. In the process of breeding, there is a problem of how to correctly assess the components of the variance. There are estimates of additive and non-additive components of the variance. In addition, the reduction in errors in the evaluation of the variance component increases the accuracy of the assessment of the breeding values $[10,11]$ and the effect of the selection. Conscientiously, the principles of animal breeding are based on the variability of the traits, without which there would be no genetic improvement. At the same time, economic values often indicate the need to reduce the variance. Therefore, in breeding programs, it is necessary to monitor and then influence this parameter

\section{Methods for assessing genetic parameters}

Statistical methods for assessing variance components have been greatly improved and improved over the last three decades, thanks to large databases [12]. Methods such as ANOVA (analysis of variances embedded in Henders model 1) and LS (Least squares method of the smallest squares that is included in Henders model 2 and 3) and their derivatives are now considered outdated and are replaced by two new methods. The first method is ML (Maximum Likelihood - maximum probability method) and its derivatives such as REML, AI REML, DF REML, EM REML [13]. With more application of computer programs, e.g. DFREML [14], MTDFREML [15] and VCE [16] gave this method the importance. Another method is BAYESIAN that uses GS (Gibbs sampling) as a variance 
estimator. In addition to these, MCMC (Markov Chain Monte Carlo) and MINQUE (Hendersenov model 4) are often mentioned in the literature.

Due to possible differences in the level of genetic parameters, depending on the applied method, when interpreting scientific results, it is very important to mention the method by which the results were obtained. Schaeffer [17] points out that there are always lower residual variances with REML than with the ML method, with the same degree of freedom (or whatever). Firat and Kumulu [18] point out that the heritability of milk yield in standard lactation was 0.3143 using the REML method, and 0.3376 using the BAYESIAN-GS method.

Table 2 shows the values of heritability for milk yield, milk fat content, and protein content in studies done in Colombia, the Netherlands and Iceland.

\begin{tabular}{|l|c|c|c|}
\hline \multicolumn{1}{|c|}{ Authors } & $\begin{array}{c}\text { Naudin } \\
\text { Hurtado- Lugo., } \\
\text { et al. 2015 }\end{array}$ & $\begin{array}{c}\text { A.P.W. de } \\
\text { Roos., et al. } \\
\mathbf{2 0 0 2}\end{array}$ & $\begin{array}{c}\text { Eiríksson } \\
\mathbf{2 0 1 7}\end{array}$ \\
\hline Milk yield & $0,38-0,05$ & $0,54-0,55$ & 0,43 \\
\hline Milk Grease & $0,67-0,11$ & $0,48-0,55$ & 0,41 \\
\hline $\begin{array}{l}\text { The protein } \\
\text { content }\end{array}$ & $0,50-0,07$ & $0,46-0,49$ & 0,39 \\
\hline
\end{tabular}

Table 2: Evaluation of the heritage of dairy characteristics by using a random regression model.

\section{Model with random regression}

A random regression model, or Random Regression model (RRM), is a newer model for the analysis of properties in which phenotypic values can be changed [19] and as such can be presented as time functions. Under the notion of a fixed effect, that is, in calculating general trends, the coefficients of regression can be treated as fixed. In addition, they can also appear as a random effect, with the aim of describing a specific production curve. Due to the distribution of the factors to which they are assigned, the coefficients vary and on the basis of this, they receive the definition of random regression coefficients. A general overview of the model with random regression in a matrix view of Mroda [20] is:

$\mathrm{y}=\mathrm{Xb}+\mathrm{Qu}+\mathrm{Zpe}+\mathrm{e}$

Where the vector $\mathrm{X}$ is an incident matrix that binds repeated measurements $y$ with fixed environmental effects $b$, random effects of the animal in the permanent effects of the environment pe, and if the vector is a random error, or unexplained effects that are often defined as the rest. $\mathrm{Q}$ and $\mathrm{Z}$ are covariance matrices where the i-th order of the matrix contains orthogonal polynomials. The vector e, or random error, includes the temporary effects of the external environment for observation in $\mathrm{y}$.
The model is that the variances are the same:

$$
\operatorname{var}\left[\begin{array}{c}
\mathrm{a} \\
\mathrm{p} \\
\mathrm{e}
\end{array}\right]=\left[\begin{array}{ccc}
\mathrm{G} \otimes \mathrm{A} & 0 & 0 \\
0 & \mathrm{P} \otimes \mathrm{I} & 0 \\
0 & 0 & \mathrm{R}
\end{array}\right] ; \mathrm{E}\left[\begin{array}{c}
\mathrm{y} \\
\mathrm{a} \\
\mathrm{p} \\
\mathrm{e}
\end{array}\right]=\left[\begin{array}{c}
\mathrm{Xb} \\
0 \\
0 \\
0
\end{array}\right]
$$

Where $G$ is the matrix of kinship, A matrix of the variation of additive genetic coefficients of random regression, $P$ is identical matrix of dimensions equal to the number of observations, I is the matrix of coefficients of random regression for constant environmental influences, and $\mathrm{R}$ represents the random error or residual variation. Due to the possible variation of the shade of the residue between Jamrozik., et al. [21] sy proposed the modified formula for R:

$\operatorname{var}[\mathrm{e}]=\operatorname{diag}\{\}$,

Where $\mathrm{k}$ equals the total number of different variations of the remainder. Rekaya., et al. [22] emphasize that a method should be developed that will allow the heterogeneous variance of the residue to be tracked as a continuous function.

Modeling the curve as functions of variables (eg age), which can be changed in time and space for each animal individually, is possible with the development of an animal model with the application of random regression coefficients. Thus, the model divides the given production curve into a fixed part, which describes the general shape of the curve that is unique to the entire population and the random part describing the specific deviation of the curve from the common shape defined in the fixed part. Using this model, fewer parameters are needed for assessing (co) variance and breeding value, and possibly It is estimated at any point along the path. In addition, Meyer [23] points out that the use of regression coefficients allows for the observation of genetic and environmental changes over time based on production functions. Covariance function (CF) serves to calculate variances and covariance parameters measured at different locations along the path and as such is defined as a continuous function. It is infinite in terms of dimension and represents the equivalent of a covariance matrix of a certain number of measurements at different ages and gives a covariance between two measurements at certain ages as a function of age [24]. A covariance function written as a random regression requires an independent variable be standardized in time [24]. Kirkpatrick., et al. [25,26] have shown that genetic and phenotypic variance are modeled as a function of time.

\section{Genetic linkage of milk yield properties}

Genetic correlations are in most cases related to the association of two traits resulting from the action of the additive effects of the gene. Knowing the strength of an association of properties has a practical significance for indirect selection, because, depending on the strength of the connection, simultaneous improvement of sev- 
eral properties can be achieved. In some cases, the improvement of one property may have a negative effect on another property. This is the case where there is a negative genetic link between the traits. Radinovic., et al. [27] examined the value of the first Holstein Holstein Friesian race in Vojvodina genetic correlations between milk yield characteristics and milk fat content. A complete, positive genetic correlation was established between the yield of milk and milk fat (0.93), while between the yield of milk and the milk fat content was negative (-0.06). Using the MTRR (Multiple Trait Random Regression Model), Kheirabadi., et al. [28] examined the genetic parameters of dairy characteristics at the first Israeli Holstein. The correlation between yield of milk, milk fat and protein in standard lactation was observed. The relationship between the observed properties was strong, positive, ranging from 0.75 (milk yield - milk yield) to 0.92 (milk yield - protein yield)

\section{Change in genetic parameters during productive life}

Heritability is the share of additive genetic variability in total phenotypic variability. Heritability (succession coefficient) is not a constant, it shows the proportion of variance caused by differences in additive the effects of the gene in a particular population and at a certain time. The decrease in additive genetic variance affects the reduction in total phenotypic variance. Lower heritability values can be changed without changes in the genotype, if environmental factors have a greater impact on the population. An increase in environmental variability that is not accompanied by a proportional increase in genetic variance leads to a decrease in heritability. Heritability is determined on data that are most often not balanced and in which the number of individuals varies by factor classes. For these reasons, it can not be considered that the impacts being tested, including the effects of inheritance, are mutually independent.

According to some studies it has been found that heritability increases with increasing lactation. Samore., et al. [29] calculated the heritability of the RR (random regression) TD (test day) model for the Holstein-Friesian race during the first three lactations in the period from 1990 to 1998 . The heritability score increased unknown from first to third lactation. In the first lactation it was 0.33 , in the second 0.34 , and the third 0.37 . For the yield of fat, it was in the first lactation of 0.30 , in the second 0.34 and the third 0.38 .

Vidic [30], Weller., et al. [31], Van Vleck and Dong [32], Jara., et al. [33], Boldman and Freeman [34], were found to increase the heritability of milk yields and milk fats with increasing age.

\section{Task and objective of work}

The aim of this research is to evaluate the genetic parameters of heritability, genetic and phenotypic correlations for milk properties (milk yield, milk fat content, and protein content) using random regression model. Before that, phenotypic parameters as well as the influence of fixed factors were calculated: race (black and red holstein), year and season of calving, and age on these properties.
Based on the literature reviewed, the following assumptions began:

- $\quad$ Race, year of calving, calving season, and age statistically have a significant impact on the milking characteristics.

- $\quad$ Age has a linear regression influence on milk properties.

- Heritability estimates will range from medium to high, depending on the age of calf.

\section{Material and Method of Work}

Material of work

The data used for the examination in this paper, and which represent the experimental part of the study, include completed lactations of the throats, which were planted in the period from 2011 to 2016, the Holstein-Friesian breed of cattle that is in the territory of AP Vojvodina. The data is taken from the reporting documentation (lists of completed lactations) of the basic breeding organizations that carry out the main breeding program for the HF race in AP Vojvodina, which is delivered to the quarterly, the main breeding organization. Prior to the statistical processing of data, incomplete data, extreme and illogical values were excluded from the database for the purpose of obtaining

The more accurate results. Statistical data processing includes 61,871 throats, black and red Holstein breeds. The characteristics that are taken into account are milk yield in kilograms (ML, kg), milk fat content in percentages (MS,\%) and protein content in percent $(\mathrm{PR}, \%)$. The effects of fixed factors (race, year of calving, calving season, lactation in order and age of calving) were examined for the observed properties. In accordance with the guidelines of the International Committee for the Control of ICAR Production, milk control can be carried out using A or B method. Taking into account the economic and organizational-technical possibilities in our country, it is a breeding program.

The use of AT4 and BT4 methods for milk control is envisaged. Control is carried out by measuring the targeted amount of milk by the measuring instruments provided, and then a representative sample ( $\min .30 \mathrm{ml}$ ) is taken from the total amount of milk to determine the content of the basic milk quality components. The equipment used during control must be approved by ICAR and regularly serviced. Control is done alternately, one month in the morning, and the next month in the evening. Exceptionally, control can be twice a day in the evening or in the morning, but not more than once a year. The allowed clearance between the two consecutive controls is from 22 to 37 days. During the calendar year in the herd, at least 11 controls must be made. The first control in the newly started lactation must be done at the earliest 5 to 7 days after calving, and at the latest between 15 and 51 days after calving, or, exceptionally, up to 80 days after calving.

Histograms 1, 2 and 3 show the distribution of data for milk yield, milk fat content, and protein content. 


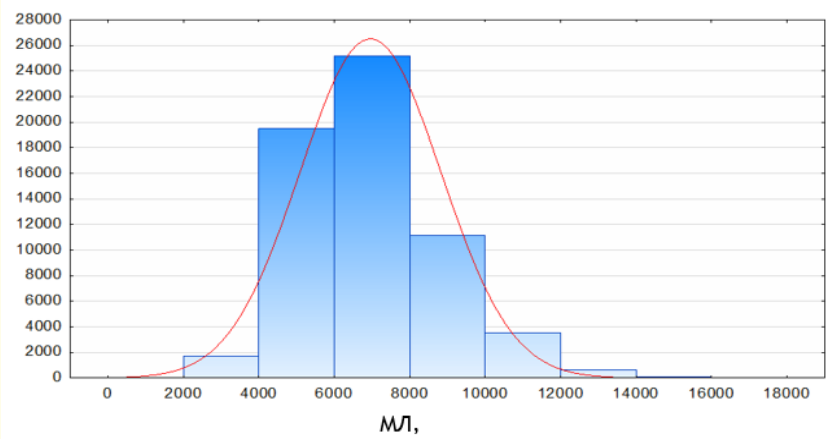

Chart 1: Data distribution for milk yield.

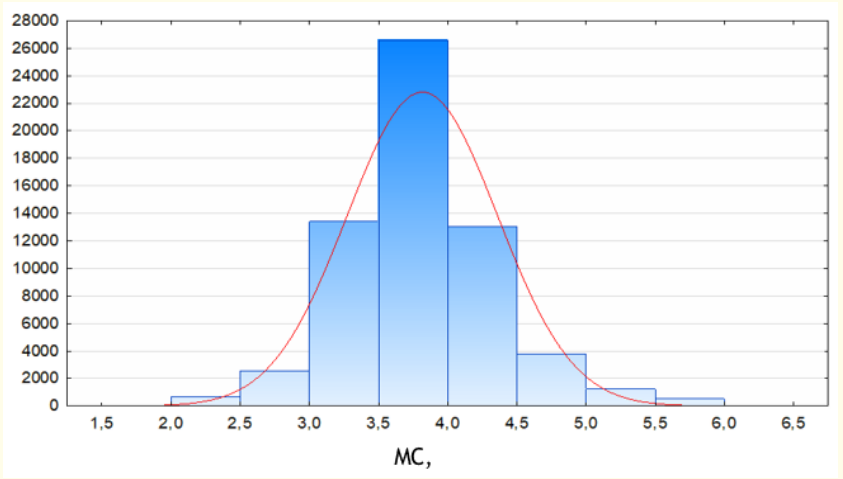

Chart 2: Distribution of data for milk fat content.

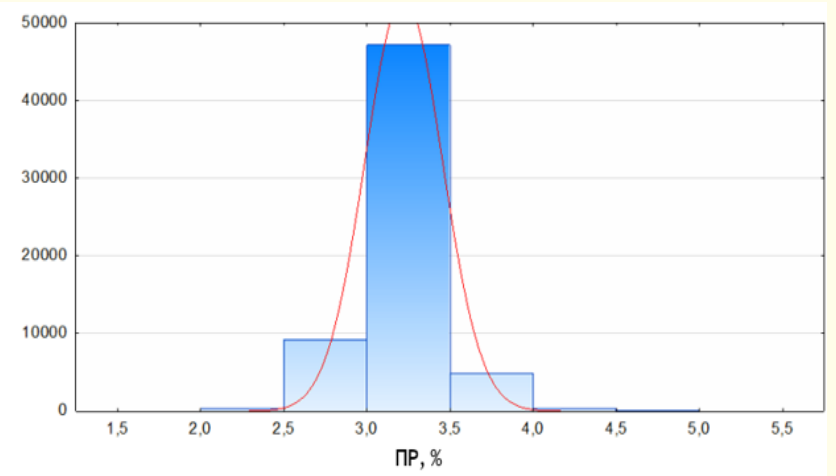

Chart 3: Distribution of data for protein content.

\section{Method of rada}

After the database was formed, the calculation of descriptive statistics, ie phenotypic parameters such as arithmetic mean), standard deviation (SD), standard mean error 0, minimum (Min), maximum (Max) and variation coefficient (CV) for the whole popu- lation and age of milk yield (ML, kg), milk fat content MS,\%) and protein content $(\mathrm{PR}, \%)$. In the assessment of the influence of fixed factors, the general linear model (GLM) was applied in the statistical program Statistica 13.0. Quantitative genetic analysis of data which included calculating the components of variations and genetic parameters, was performed in the WOMBAT [35] software by limiting maximum probability using a random regression model. The mathematical model had the following look:

Yijklmn $=\mu+\mathrm{Ri}+\mathrm{Gtj}+\mathrm{Setk}+\mathrm{Ll}+\mathrm{Stm}+$ eijklmn

Wherein

$\mathrm{y}$ - Phenotypic value of the observed properties

$\mu$ - General mean value

Ri - Fixed impact of race

Gtj - Fixed impact of the year of calving Setk - fixed seasonal effects of Ll season - fixed lactation effect in order

Stm - The fixed impact of age on calving

e - Uncontrolled influences (error)

\section{Results of Work with Discussion}

Phenotypic parameters

Using the descriptive statistics, the phenotypic parameters are shown, which are shown in table 3.

From Table 3 we see that the same number of throats is included in the analysis for all three properties. The average amount of milk in kilograms was $6916,518 \mathrm{~kg}$, average milk fat content 3,80\% and average protein content of $3,21 \%$. The absolute variability of the properties expressed in standard deviation was $1861.375 \mathrm{~kg}$ for the amount of milk, $0.541 \%$ for the fat content and $0.231 \%$ for the protein content. The relative variability expressed by the coefficient of variation was $26.91 \%$ for the amount of milk, the content milk fat $14.22 \%$ and protein content $7.20 \%$. The population of Holstein-Friesian cows in Vojvodina has not reached its maximum in the context of production or productivity. Genetic improvement is taking place very quickly, especially lately, thanks to the improvement of knowledge, statistical methods and computer techniques, successful implementation of the probe testing and wider application of artificial insemination. The variability of the characteristics observed at the genetic and phenotypic level enables us to genetically improve them. The first assumption on which this work was based was that milk yield, milk fat content and protein content in the territory of Vojvodina were lower than the genetic potential of this breed. In Table 1, from the literature review, it is observed that

\begin{tabular}{|l|c|l|l|l|l|l|l|}
\hline Property & \multicolumn{1}{c|}{$\mathbf{n}$} & \multicolumn{1}{c|}{-} & \multicolumn{1}{c|}{ Min } & \multicolumn{1}{c|}{ Max } & \multicolumn{1}{c|}{ SD } & \multicolumn{1}{c|}{ CV, $\%$} \\
\hline МЛ, $\mathrm{kg}$ & 61.871 & $6.916,51$ & 7,48 & $2.505,00$ & $15.982,00$ & $1.861,37$ & 26,91 \\
\hline МС, $\%$ & 61.871 & 3,80 & 0,0021 & 2,00 & 5,99 & 0,54 & 14,22 \\
\hline ПР, \% & 61.871 & 3,21 & 0,0009 & 2,00 & 4,86 & 0,23 & 7,20 \\
\hline
\end{tabular}

Table 3: Phenotypic parameters of milk yield

N: Number of Throats; ${ }^{-}$: Average Milk Yield/Milk Fat and Protein Content; ${ }^{-}$: Standard Error of Mean Value; Minimum Value; Maximum Value; SD: Standard Deviation; CV: Coefficient of Variation in Percentages. 
the leading country in the milk yield per cow in 305 days of lactation was Hungary $(9,685 \mathrm{~kg})$. The content of protein and milk fat was the highest in Germany (3.44\% and 4.17\%) and Denmark(3.44 and $4.25 \%)$. The content of milk fat was the lowest in Hungary (3.67\%), and the protein content was lowest in Serbia (3.19\%) and the UK (3.19\%). According to the expert report (Main Breeding Organization, 2018) in 2017 in the territory of Vojvodina, the milk production of Holstein Friesian breed at the whole lactation level was 7,722 kg of milk, $294 \mathrm{~kg}$ of milk fat and $252 \mathrm{~kg}$ of protein, which is an increase compared to 2016 yield of milk by $125 \mathrm{~kg}$, milk fat for $5 \mathrm{~kg}$ and milk proteins by $6 \mathrm{~kg}$.

Phenotypic parameters of milk, milk fat and protein yield by age are shown in tables 4 to 6 .

\begin{tabular}{|l|c|c|c|c|c|c|c|}
\hline Age & $\mathbf{n}$ & - & - & Min & Max & SD & CV, \% \\
\hline 2 & 16.633 & $6.806,50$ & 13,941 & $2.505,00$ & $15.982,00$ & $1.794,49$ & 26,36 \\
\hline 3 & 14.730 & $6.922,45$ & 15,5574 & $2.542,00$ & $15.688,00$ & $1.888,16$ & 27,27 \\
\hline 4 & 11.593 & $7.093,25$ & 18,3000 & $2.573,00$ & $15.813,00$ & $1.970,38$ & 27,77 \\
\hline 5 & 8.614 & $7.007,24$ & 20,0057 & $2.545,00$ & $15.592,00$ & $1.856,76$ & 26,49 \\
\hline 6 & 6.003 & $6.885,95$ & 23,2828 & $2.506,00$ & $15.806,00$ & $1.803,93$ & 26,19 \\
\hline 7 & 3.190 & $6.755,69$ & 31,4598 & $2.697,00$ & $15.767,00$ & $1.776,29$ & 26,29 \\
\hline 8 & 1.108 & $6.563,19$ & 50,5838 & $2.955,00$ & $13.537,00$ & $1.863,76$ & 26,65 \\
\hline
\end{tabular}

Table 4: Phenotypic parameters of milk yield by age.

n: Number of Throats; ${ }^{-}$: Average Milk Yield/Milk Fat and Protein Content; ${ }^{-}:$Standard Error of Mean Value; Minimum Value; Maximum Value; SD: Standard Deviation; CV: Coefficient of Variation in Percentages.

\begin{tabular}{|l|l|l|l|l|l|l|l|}
\hline Age & \multicolumn{1}{c|}{$\mathbf{n}$} & - & - & \multicolumn{1}{c|}{ Min } & \multicolumn{1}{c|}{ Max } & \multicolumn{1}{c|}{ SD } & CV, $\%$ \\
\hline 2 & 16.633 & 3,78 & 0,0040 & 2,00 & 5,99 & 0.52 & 13,74 \\
\hline 3 & 14.730 & 3,79 & 0,0045 & 2,02 & 5,99 & 0.54 & 14,43 \\
\hline 4 & 11.593 & 3,79 & 0,0051 & 2,00 & 5,99 & 0,54 & 14,45 \\
\hline 5 & 8.614 & 3,82 & 0,0058 & 2,00 & 5,99 & 0,54 & 14,31 \\
\hline 6 & 6.003 & 3,82 & 0,0070 & 2,00 & 5,99 & 0,54 & 14,33 \\
\hline 7 & 3.190 & 3,83 & 0,0096 & 2,04 & 5,97 & 0,54 & 14,15 \\
\hline 8 & 1.108 & 3,88 & 0,0168 & 2,02 & 5,96 & 0,56 & 14,45 \\
\hline
\end{tabular}

Table 5: Phenotypic parameters of fat yield by age

n: Number of Throats; ${ }^{-}:$Average Milk Yield/Milk Fat and Protein Content; ${ }^{-}:$Standard Error of Mean Value; Minimum Value; Maximum Value; SD: Standard Deviation; CV: Coefficient of Variation in Percentages.

\begin{tabular}{|l|l|l|l|l|l|l|l|}
\hline \multicolumn{1}{|c|}{ Age } & \multicolumn{1}{c|}{$\mathbf{n}$} & - & \multicolumn{1}{c|}{ Min } & \multicolumn{1}{c|}{ Max } & \multicolumn{1}{c|}{ SD } & \multicolumn{1}{c|}{ CV, \% } \\
\hline 2 & 16.633 & 3,19 & 0,0017 & 2,00 & 4,55 & 0,22 & 7,00 \\
\hline 3 & 14.730 & 3,22 & 0,0018 & 2,00 & 4,67 & 0,22 & 7,10 \\
\hline 4 & 11.593 & 3,21 & 0,0021 & 2,00 & 4,86 & 0,23 & 7,29 \\
\hline 5 & 8.614 & 3,21 & 0,0025 & 2,01 & 4,81 & 0,23 & 7,26 \\
\hline 6 & 6.003 & 3,20 & 0,0030 & 2,00 & 4,52 & 0,23 & 7,37 \\
\hline 7 & 3.190 & 3,20 & 0,0042 & 2,00 & 4,79 & 0,24 & 7,55 \\
\hline 8 & 1.108 & 3,21 & 0,0072 & 2,09 & 4,45 & 0,24 & 7,50 \\
\hline
\end{tabular}

Table 6: Phenotypic parameters of protein yield by age.

n: Number of Throats; ${ }^{-}:$Average Milk Yield/Milk Fat and Protein Content; ${ }^{-}:$Standard Error of Mean Value; Minimum Value; Maximum Value; SD: Standard Deviation; CV: Coefficient of Variation in Percentages.

Table 4 presents the values in which phenotypic parameters are displayed by age, from second to eighth year. The highest average milk yield was achieved in the fourth year $(7,093.25 \mathrm{~kg})$ with the highest standard deviation $(1,970.38 \mathrm{~kg})$. The average value of milk yield in the second year was $6,806.50 \mathrm{~kg}$, and in the last 6,563.19 $\mathrm{kg}$. The pronounced variability of milk yield in this study is due to the influence of various factors which in their operation can be current and lasting. Current influences are expressed in a shorter time interval, but continuously change the intensity and direction of action. Permanent influences can emerge from an environment in which individuals produce production or are the result of the influence of a hereditary basis, which is characteristic of each individual.

The average value of fat yield in the second year was $3.78 \%$, and in the last $3.88 \%$. The standard error is the highest in the eighth 
year, which is 0.0128 higher compared to the other. The standard deviation was $0.52 \%$ in the second year and in the last $0.56 \%$. The coefficient of variation slightly increased from 13.74 in the second year to 14.45 in the latter. The highest average milk fat content was in the eighth year (3.88\%) and the highest standard deviation $(0.56 \%)$, contrary to milk yield values, which in the eighth year had the lowest value. The variability of the properties observed over the coefficient of variation was highest in the fourth and eighth years $(14.45 \%)$.

Based on the results in Table 6, we see that the average protein yield in the second year was $3.19 \%$, in the eighth $3.21 \%$. The standard error increased from 0.0017 in the second year to 0.0072 in the eighth year. The standard deviation in the second year was $0.22 \%$, and in the last $0.24 \%$. The coefficient of variation grew from $7.00 \%$ in the second year to $7.50 \%$ in the latter, and the variability was the highest in the seventh year of $7.55 \%$.

The influence of fixed factors and the selection of the model for the assessment of milk personal parameters

In order to construct a model for the assessment of genetic parameters, random, fixed and regression influences are first defined. Accidental effects in the model were the effects of animals. From the fixed factors as a source of variability, the race (red and black Holstein), year of calving, season of calving, lactation in order and age were taken. Tables 7, 8, 9 show the results of a single-factorial analysis of variance (degrees of freedom, $\mathrm{F}$ and $\mathrm{P}$ values, as well as the coefficient of determination) or the influence of fixed factors on the observed properties.

\begin{tabular}{|l|l|l|l|l|}
\hline Source of variability & d. f. & F & P & $\mathbf{R}^{\mathbf{2}}$ \\
\hline Race & 1 & $4.301,200$ & 0,0000 & 0,0650 \\
\hline Year & 5 & 23,0393 & 0,0000 & 0,0018 \\
\hline Season & 3 & 171,5841 & 0,00 & 0,0082 \\
\hline Lactation per order & 4 & 105,814 & 0,0000 & 0,0067 \\
\hline Age & 6 & 41,5925 & 0,0000 & 0,0040 \\
\hline
\end{tabular}

Table 7: One-factorial analysis of the variance for milk volume d. f.: Degrees of Freedom; F: f coefficient; $P<0,01$ Statistically Significant Influence; $\mathrm{R}^{2}$ : Determination Coefficient.

\begin{tabular}{|l|l|l|l|r|}
\hline Source of variability & D.f. & \multicolumn{1}{|c|}{$\mathbf{F}$} & \multicolumn{1}{c|}{$\mathbf{P}$} & $\mathbf{R}^{\mathbf{2}}$ \\
\hline Race & 1 & $866,183^{* *}$ & 0,0000 & 0,0138 \\
\hline Year & 5 & $11,9435^{* *}$ & 0,0000 & 0,0009 \\
\hline Season & 3 & $46,4574^{* *}$ & 0,00 & 0,0022 \\
\hline Lactation per order & 4 & $17,7196^{* *}$ & 0,0000 & 0,0011 \\
\hline Age & 6 & $12,6039^{* *}$ & 0,0000 & 0,0012 \\
\hline
\end{tabular}

Table 8: One-factorial analysis of variance for the quantity of milk fat

\section{d. f.: Degrees of Freedom; F: f coefficient; P <0,01 Statistically Significant Influence; $\mathrm{R}^{2}$ : Determination Coefficient.}

Based on the results in Table 7, we see that each investigated factor had a very significant effect on the observed properties $(P$ $<0.01$ ). The determination coefficient for the race was 0.0650 , for

\begin{tabular}{|l|l|l|l|l|}
\hline Source of variability & \multicolumn{1}{|c|}{ D.f. } & \multicolumn{1}{c|}{ F } & \multicolumn{1}{c|}{$\mathbf{P}$} & $\mathbf{R}^{\mathbf{2}}$ \\
\hline Race & 1 & $23,146^{* *}$ & 0,0000 & 0,0003 \\
\hline Year & 5 & $18,4482^{* *}$ & 0,0000 & 0,0014 \\
\hline Season & 3 & $115,5738^{* *}$ & 0,00 & 0,0055 \\
\hline Lactation per order & 4 & $30,0229^{* *}$ & 0,0000 & 0,0019 \\
\hline Age & 6 & $17,2530^{* *}$ & 0,0000 & 0,0016 \\
\hline
\end{tabular}

Table 9: One-factorial analysis of the variance for the amount of protein.

d. f.: Degrees of Freedom; F: f coefficient; $P<0,01$ Statistically

Significant Influence; $\mathrm{R}^{2}$ : Determination Coefficient.

year 0.0018 , for the season 0.0082 , for lactation in the order of 0.0067 and for age 0.0040 . The coefficients of the determination show the share of the total variability of the dependent variable, explained by the independent variable or the factors involved. The greater the value of the determination coefficient, the higher it is the importance of the factor included in the model in explaining the variability of the observed variable. The obtained $P$ values are in accordance with Petrović., et al. [36], which established a statistically significant effect $(\mathrm{P}<0.01)$ of the year and season of calving on variation in yield of milk and milk fat. Trifunović., et al. [37] found statistically significant $(\mathrm{P}<0.01)$ influence of lactation order, year and season of calving on examined milk properties.

Table 8 shows the same effects that had a high signifikantan impact on the milk fat content $(\mathrm{P}<0.01)$. The ratio of determination for the race was 0.0138 , in the year 0.0009 , for the season 0.0022 , for lactation in line 0.0011 and for age 0.0012 .

The results in table 9 indicate a statistically high significant impact of fixed factors on the protein content in milk. The coefficient of determination for the race was the smallest and amounted to 0.0003 , in the year 0.0014 , season 0.0055 , lactation in line 0.0019 and age 0.0016 . The greatest impact on the amount of protein had a season where the value of coefficient determination amounted to 0.0055 .

In charts 4, 5 and 6, it shows linear regression impact of age on the surveyed traits, milk yield, milk fat content and protein content. The milknessdecreasedonaveragefor $45 \mathrm{~kg}$, the other way, the grease increased by $0.014 \%$, and the protein slightly decreased by $0.0003 \%$ with age.

Table 10 shows a model for testing system factors on the characteristics of dairy in all lactations formed by inclusion of race, year, season, lactation in order and linear regression impact of age. The results of F-Test have confirmed the high significant impact of race, year, season and age $(\mathrm{P}<0.01)$ on the yield of milk, the content of dairy fat and protein, except the lactation in the order that is not Statistical significantly.

Impact on the yield of milk and age which did not significantly affect the protein content. The coefficient of determination $\mathrm{R}^{2}$ was for the yield of milk 0.081 , the contents of dairy fat 0.516 and protein 0.009 . The race was the most affected by dairy and dairy 


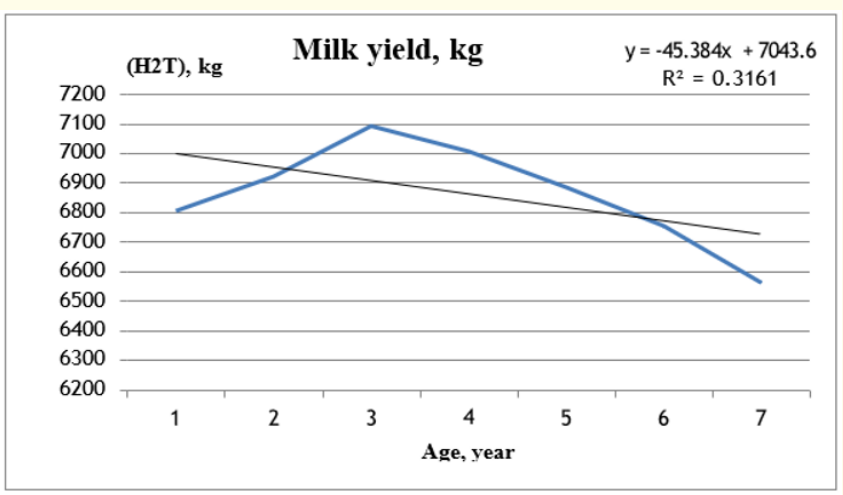

Chart 4: Linear regression effect on milk volume.

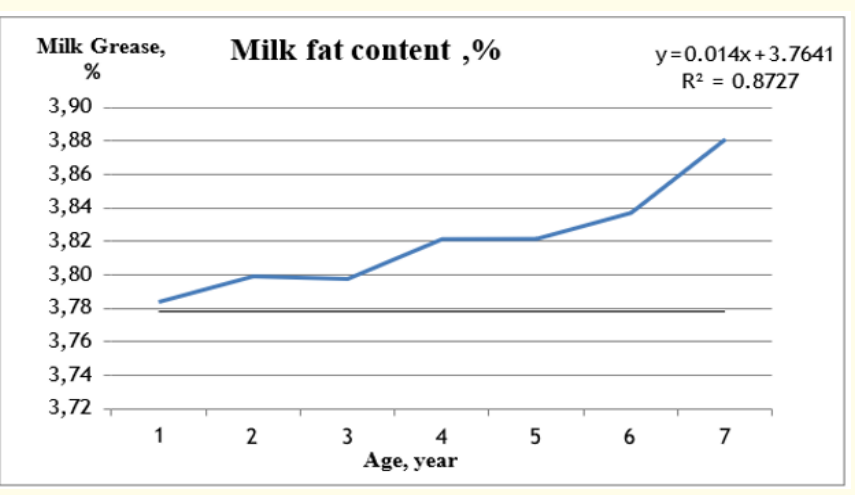

Chart 5: Linear regression effect on the amount of dairy fat.

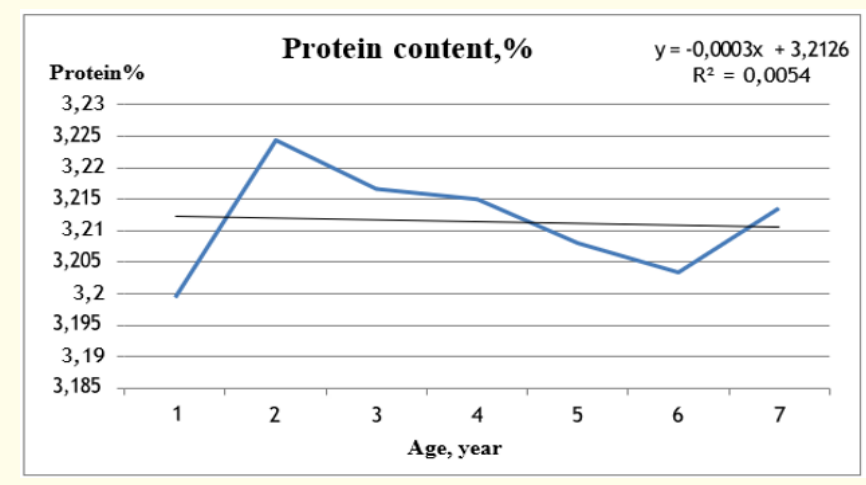

Chart 6: Linear regression effect on the amount of protein.

\begin{tabular}{|l|l|l|r|l|}
\hline \multirow{2}{*}{ Source Variability } & \multirow{2}{*}{ d. f. } & \multicolumn{3}{|c|}{ F Value } \\
\cline { 3 - 5 } & & \multicolumn{1}{|c|}{ МЛ, kg } & MC, \% & \multicolumn{1}{|l}{ ПР, \% } \\
\hline Race & 1 & $4.251,30^{* *}$ & $881,33^{* *}$ & $32,6^{* *}$ \\
\hline Year & 5 & $18,62^{* *}$ & $18,99^{* *}$ & $22,5^{* *}$ \\
\hline Season & 3 & $117,71^{* *}$ & $48,35^{* *}$ & $114,0^{* *}$ \\
\hline Lactation in order & 4 & $140,14^{\text {нз }}$ & $0,73^{* *}$ & $27,7^{* *}$ \\
\hline Age & 1 & $144,47^{* *}$ & $6,17^{* *}$ & $1,2^{\text {нз }}$ \\
\hline $\mathrm{R}^{2}$ & & 0,081 & 0,018 & 0,009 \\
\hline
\end{tabular}

Table 10: Fixed part of the model for genetic analysis.

D. F.: Degrees of freedom; F-F Quoter;** $\mathrm{P}<0,01$

$$
{ }^{*} \mathrm{p}<0,05 \text { Hз } \mathrm{p}>0,05 \text {. }
$$

content, while the season had the greatest impact on the protein content.

Markovic [38] indicates that the coefficients of determination (R2) vary significantly depending on the number of impacts that are included in the model. From table 10, we see that the value of the coefficient of determination ranges from 0.009 to 0.081 . For yield (0.081) from those established by markovic [38] (0.31). When we compare the resulting values of the coefficient of Trivunovic [39] in all the lactation for milk yield and content Milk fats including farm factors, age of birth, age, veal and lactation season, it is visible that the values are higher $(0.290$ and 0.502$)$ compared to the value of this work ( 0.081 and 0.018$)$. Also, the same author insists that $\mathrm{R}^{2}$ values are considerably more in the models when, as a fixed factor, the interaction of the farm, year and season, but when each of the individual factors are taken separately.

\section{Genetic parameters}

Determining genetic parameters is necessary to select the method of selection and to perceive its success. According to the Psychic [40] They serve to identify sources of variability, study the natural action of genes that determine certain traits, evaluate genetic progresses and evaluate the breeding values, compare the effectiveness of different methods Selection and model selection criteria. The values of the heritage coefficients depend on the difference in gene effects, from the selected method for calculating the rating, the degree of elimination of different systematic impacts of the environment and the specimen size. The heritage values gained by the accidental regression model were larger compared to the values obtained by ML and REML methodology, which was verified by the examination of the literature. Trivunovic [39] insists that the values of the heritage acquired by the REML methodology were lower than THE heritage obtained by ML methodology and believes that it is primarily, due to the great phenotype variability of the quality of milk yields, milk fat and protein, and because of the application of a mixed model in which the impact of more systemic environmental factors has been eliminated. It is characteristic that in numerous researches $[41,42]$ in which the heritage is determined by Interclass correlation OR REML methodology, in models with similar number of affected system impacts of the resulting value of less than 0.20 . However, if a smaller number of environmental factors were taken into account, there would be a considerably higher value of the heritage. Especially the difference between the model with and without the farm's impact. It confirms the great amount of dairy results by and indicates the importance of inclusion in this effect in a genetic assessment. This should be especially taken into account when compared to the heritage of other researches, in which a smaller number of fixed influences have been applied to one or fewer farms. Relatively low heritage values may be greatly explained and that the systematic impacts result in increasing the variance of the environment, which is why the additive genetic Variance (\%) in total Fenotipska Variance proportionally decreases. 
Currently, in most countries for genetic assessment of dairy cattle are used by TD models, and less traditional lactic models, claims in its work Mosharraf., et al. [43]. In comparison with the lactic MODELS, the TD model can take into account the interaction of the test Season. For example, if the lactation test was in the rainy period, day or after, the meal would have been altered in relation to other dairy records. The advantages of RR model are that they can analyse the environmental effects, which are specific to each day of control (TD) and are permitted to distinguish the shape of the lactation by any animal. Analysis of the model with accidental regression generally gives greater value to the heritage than the application of ML methodology. Residual variance, with this and accuracy of the applied methods in the TD model, is lower than other models, regardless of the degree of freedom. There is a number of reasons for the introduction of the TD model in practice due to the reduction of the cost of dairy control, reducing the generational interval, better adjustments for external environment factors, etc. Genetic parameters by using REML methodologies are calculated using a mixed linear model in the "WOMBAT" statistical program. Genetic parameters are calculated by the heritage, genetic and phenotype cores. These parameters are displayed in table 11.

\begin{tabular}{|l|c|c|c|c|c|c|c|}
\hline Age & $\mathbf{2}$ & $\mathbf{3}$ & $\mathbf{4}$ & $\mathbf{5}$ & $\mathbf{6}$ & $\mathbf{7}$ & $\mathbf{8}$ \\
\hline 2 & 0,103 & 0,058 & $-0,078$ & $-0,180$ & $-0,240$ & $-0,274$ & $-0,296$ \\
\hline 3 & 0,507 & 0,041 & 0,092 & 0,086 & 0,079 & 0,072 & 0,066 \\
\hline 4 & $-0,348$ & 0,632 & 0,122 & 0,333 & 0,377 & 0,399 & 0,410 \\
\hline 5 & $-0,568$ & 0,421 & 0,969 & 0,242 & 0,563 & 0,604 & 0,626 \\
\hline 6 & $-0,648$ & 0,328 & 0,939 & 0,995 & 0,331 & 0,713 & 0,741 \\
\hline 7 & $-0,687$ & 0,277 & 0,920 & 0,988 & 0,999 & 0,385 & 0,803 \\
\hline 8 & $-0,711$ & 0,246 & 0,907 & 0,983 & 0,996 & 0,999 & 0,419 \\
\hline
\end{tabular}

Table 11: Heritage (diagonals) and correlation (above the phenotype diagonal, below the genetic diagonal) for milk yield in all full lactations.

It is said that the heritage for milk yield has grown with the increase of age. The lowest heritage was in the third year 0.041, and the largest in the eighth 0.419 . Genetic cores are located on the lower side of the diagonal and are high-strong and positive.

Between the second and third and third with the other age. Negative medium-sized and strong genetic correlations are calculated between the second year with all other (except the third) age. Strong to complete positive correlation are calculated from the fourth to eighth age. Fenotipske correlations are shown on the top and are weak and positive between the second and third and the other age. Negative and medium-sized phenotype correlations are calculated between others with all other (except with third) years of age. High-grade positive ones are calculated from the fourth and eighth years of age.

Table 12 shows genetic parameters for the feature of dairy fat.

In Table 12, the heritage for the milk fat content increased from the other where it was 0.389 until the eighth of the year, where it was 0.490. Genetic cores were positive, strong until complete, while the phenotype cores were medium-strong and positive.

\begin{tabular}{|l|c|c|c|c|c|c|c|}
\hline Age & $\mathbf{2}$ & $\mathbf{3}$ & $\mathbf{4}$ & $\mathbf{5}$ & $\mathbf{6}$ & $\mathbf{7}$ & $\mathbf{8}$ \\
\hline 2 & 0,389 & 0,438 & 0,439 & 0,439 & 0,438 & 0,436 & 0,433 \\
\hline 3 & 0,988 & 0,403 & 0,445 & 0,447 & 0,448 & 0,448 & 0,447 \\
\hline 4 & 0,992 & 0,998 & 0,418 & 0,454 & 0,457 & 0,459 & 0,460 \\
\hline 5 & 0,982 & 0,993 & 0,998 & 0,435 & 0,465 & 0,469 & 0,472 \\
\hline 6 & 0,971 & 0,984 & 0,993 & 0,998 & 0,452 & 0,478 & 0,483 \\
\hline 7 & 0,957 & 0,974 & 0,986 & 0,994 & 0,999 & 0,471 & 0,492 \\
\hline 8 & 0,941 & 0,961 & 0,977 & 0,988 & 0,995 & 0,999 & 0,490 \\
\hline
\end{tabular}

Table 12: Heritage (diagonals) and correlation (above the phenotype diagonal, below the genetic diagonal) for the content of dairy fat in all the whole lactic.

The grades of genetic parameters for protein content show that the heritage had the smallest value in the third year 0.323 and the largest in the eighth year of age 0.393 (Table 13). Genetic cores were positive and strong until complete, and the phenotyipic medium-strong and positive.

\begin{tabular}{|l|c|c|c|c|c|c|c|}
\hline Age & $\mathbf{2}$ & $\mathbf{3}$ & $\mathbf{4}$ & $\mathbf{5}$ & $\mathbf{6}$ & $\mathbf{7}$ & $\mathbf{8}$ \\
\hline 2 & 0,325 & 0,321 & 0,313 & 0,304 & 0,292 & 0,279 & 0,266 \\
\hline 3 & 0,992 & 0,323 & 0,322 & 0,319 & 0,314 & 0,307 & 0,299 \\
\hline 4 & 0,967 & 0,992 & 0,327 & 0,322 & 0,344 & 0,333 & 0,331 \\
\hline 5 & 0,929 & 0,968 & 0,992 & 0,337 & 0,351 & 0,357 & 0,360 \\
\hline 6 & 0,879 & 0,933 & 0,972 & 0,993 & 0,352 & 0,377 & 0,386 \\
\hline 7 & 0,824 & 0,890 & 0,941 & 0,976 & 0,994 & 0,371 & 0,408 \\
\hline 8 & 0,767 & 0,843 & 0,905 & 0,950 & 0,980 & 0,995 & 0,393 \\
\hline
\end{tabular}

Table 13: Heritage (diagonals) and correlation (above the phenotype diagonal, below the genetic diagonal) for protein content in all of the lactations.

Djurdjevic and Vidovic [44] are using mixed models (BLUP), in which the equation was involved in the accidental impact of the bull-father and the fixed impact of the region, the year and the season of birth, pointed to the reduction of the heritage characteristics of dairy by increasing the number of lactation. Swalve [45], based on the data on the daily milk volume, assessed the heritage taking into account the records of the test day directly in the form of a rebirth model for milk yield $(\mathrm{kg})$, in standard lactation $(\mathrm{H} 2=$ 0.39), while the heritage Milk fat was lower and amounted to 0.32 . In table 2, from the literature review, they were given results of research by using RR, Test day model. Naudin Hurtado-Lugo., et al. [46] from Colombia in his work stated that the residual variances were modeled by using homogenous and heterogenic structures. In the model with straight variance of the remainder of milk yield, the content of dairy fat and Proteins are divided into four classes (from 1-on and 2-month to 4, from 5 to 8 and 9 to 10 month). They indicate that the residual variance of all characteristics has declined from the fifth to the tenth month, while the additive genetic Variance for The yield of milk and Dairy fats have shown the same trend as the phenotyipic and residual variance, with higher values at the end of lactation. The authors suggest that the heterication of residual variability can be attributed to factors such as a phase of the respite or physiological state of the body because these factors are not included in the model due to lack of information. Heritage 
for milk yield, milk fat and protein was moved 0.05 to $0,38,0,11$ to $0,67,0,07$ to 0.50 and 0.08 to 0.50 . They also say that genetic cores for these traits have been ranging from- 0.56 to 0.96 depending on the month of control. The Phenotypi correlations were lower with the increase of the interval between test days and control, and they were less than genetic, as in this work. When we compare the research Jón Hjalti Eiríksson [47], we can conclude that there were no significant differences in the assessment of the daily yields ' additive genetic variance, based on which the characteristics were jointly assessed in the analysis. Genetic variance of the first The lactation was similar during lactation, while the phenotype variations of the second and third lactation were the highest at the beginning of lactation. Their heritage was the largest in the first lactation of $0.43,0.41$ and 0.39 for milk yield (ML, kg), milk fat content (MS,\%) and protein content $(\mathrm{PS}, \%)$. The same authors conclude that the application of the model with accidental regression for production features is beneficial and can result in genetic progress of Iceland's population by $11 \%$. In a survey conducted in the Netherlands, A.P.W. de Roos., et al. [48] said that the genetic and permanent environmental variability for the daily yield was constant in the middle of lactation and slightly higher at the end of the second and third lactation. Genetic correlation were 0.80 in the first lactation, 0.65 in other lactation and 0.55 in Third. According to the Iran research, Mosharraf., et al. [43] they say that the variation of the heritage is largely affected by the change of additive genetic variability during lactation. Also stated that the heritage for the daily milk yield in the standard lactation was the highest between 4 and 5 years, and then decreased Reduce the number of records or increase the phenotype variance due to the increase of environmental variance.

\section{Conclusion}

Based on the results obtained in this work, we may conclude the following

1. Total milk yield for the entire lactation averaged $6,916.51$ $\mathrm{kg}$, with average milk fat content $3.80 \%$ and average protein content $3.21 \%$. Standard high-value errors were low.

2. Absolute variability expressed in the standard deviation of milk yield for all lactation was $1,861.37 \mathrm{~kg}$, for milk fat content $0.54 \%$ and protein content $0.23 \%$. Relative variability expressed in the coefficient of variation was $26.91 \%$ for milk yield, $14.22 \%$ for dairy fat and $7.20 \%$ for protein content.

3. Fixed factors, races, years, seasons, lactation in order and age have statistically greatly influenced the yield of milk, fat and protein. The biggest impact on milk and dairy yield, i.e. the largest $\mathrm{F}$ test value had a breed, for milk yield and content of dairy, while the season had the greatest impact on the amount of protein.

4. The heritage for milk yield (ML, $\mathrm{kg}$ ) had a tendency of growth from third year to eighth year (0.041 to 0.419 ), for dairy content (MS,\%) From the second to eighth year (0.389 to 0.490 ) and for protein content (PS,\%), from third to eighth year ( 0.323 to 0.393 ).
5. The genetic and phenotype correlation between the studied characteristics were the following: for milk yield (ML, kg) The negative connection of the other with the other age of age (except with the third) was calculated, while the other values were positive. For milk fat content (MS,\%) Genetic coration is strong until complete, and High-grade fenotipan. For protein content (PS,\%) Genetic correlation is strong until complete, and the phenotyphic are medium-sized.

The Modei regression Model provides continuous observation over time and is able to include heterogenic variance and covariance among the measures, including the days (not questioned in this survey), with a potentially reduced number of parameters compared to the Model for multiple attributes. In addition to the features of milk, dairy, and protein, it can be used for other characteristics such as for example. Number of somatic cells or for testing of your quality. Based on the calculated absolute and relative indicators of variability of the variables of the surveyed qualities, you can say that it is possible to achieve genetic progress in the observed population. This can be achieved by selection without enlisting genes from other populations.

\section{Bibliography}

1. Bourdon RM. "Understanding animal breeding". Journal of Animal Science 79 (2000): 1713-1722.

2. Meinert TR., et al. "Estimates of Genetic Trend in an Artificial Insemination Progeny Test Program and their Association with Herd Characteristics". Journal of Dairy Science 75 (1992): 2254-2264.

3. Čobić T I and Antov G. "Beef-milk production". Faculty of Agriculture, University of Novi Sad (1996): 708.

4. Main kennel organization. "Expert report and results of the activities of the implementation of the kennel programs in Vojvodina for 2017". Year, Faculty of Agriculture, University of Novi Sad, 181 str (2018).

5. Main Kennel Program for Holstein-Frisijsky Rasy cattle in AP Vojvodina. University of Novi Sad, Faculty of Agriculture, Department of Livestock (2014).

6. ICAR. www.icar.org.

7. Van Arendonk J., et al. "Breeding Value Estimation". Lecture notes for E250-222, Wageningen University, Animal Science, Animal Breeding and Genetics Group (2000).

8. Hill W. "Heterogeneity of Genetic and Environmental Variance of Quantitative Traits". Indian Society of Agricultural Statistics 57 (2004): 49-63.

9. Thompson R., et al. "Estimation of quantitative genetic parameters". Philosophical Transactions of the Royal Society B 360 (2005): 1469-1477.

10. Henderson CR. "Comparison of Alternative Sire Evaluation Methods". Journal of Animal Science 41 (1973): 760-770. 
11. Schaeffer LR. "Sire and Cow Evaluation under multiple trait Models". Journal of Dairy Science 67 (1984): 1567-1575.

12. Thompson R. "A review of genetic parameter estimation". Proceedings of the 7th републичка селекцијска служба. Montpellier, France (2002).

13. Meyer K. "Present status of Knowledge about statistical procedures and algorithms to estimate Variance and Covariance components". Proceedings of the 4th WCGALP 13 (1990): 407411. Edinburgh, Scotland.

14. Meyer K. "DFREML. A set of programs to estimate Variance Components under and individual Animal model". Journal of Dairy Science 69 (1988): 33-44.

15. Boldman KG., et al. "Manuel for use of MTDFREML. A set of programs to obtain estimates of variances and covariances". U.S. Departments of Agriculture, Agricultural research service (1995).

16. Groeneveld E. "VCE-A Multivariate multimodel REML (Co)variance component estimation program". Proceedings of the 5th WCGALP Guelph, Canada 22 (1994): 46-50.

17. Schaeffer LR. "Quantitative genetics and animal models. Lecture notes for ANSC*6370 - University of Guelph, department of animal and Poultry science". Ontario, Canada (1999).

18. Firat., et al. "Genetic Parameters for Milk Yield of Turkish Holestein- Friesian cows using Bayesian analyses". Proceedings of the 7th WCGALP. 17-27, Montpellier, France (2002).

19. Schaeffer LR. "Multiple-Country Comparison of Dairy Sires". Journal of Dairy Science 77 (1994): 2671- 2678.

20. Mrode RA. "Linear Models for the Prediction of Animal Breeding Values". 2nd And Publishing company, Cambridge, MA. (2005): 58.

21. Jamrozik J., et al. "Comparison of possible covariates for use in a random regression model for analyses of test day yields". Journal of Dairy Science 80 (1997): 2550-2556.

22. Rekaya R., et al. "Assessment of heterogeneity of residual variances using changepoint techniques". Genetics Selection Evolution 32 (2000): 383-394.

23. Meyer K. "Restricted maximum likelihood to estimate variance components for animal models with several random effects using a derivative-free algorithm". Genetics Selection Evolution 21 (1998): 317-340.

24. Meyer K and Hill WG. "Estimation of genetic and phenotypic covariance functions for longitudinal or repeated records by restricted maximum likelihood". Livestock Production Science 47 (1997): 185-200.

25. Kirkpatrick M., et al. "Analyses of the inheritance, selection and evolution of growth trajectories". Genetics 124 (1990): 979993.
26. Kirkpatrick M., et al. "Estimating the covariance structure during growth and ageing, illustrated with lactation in dairy cattle". Genetics Research64 (1994): 57-69.

27. Ravinovic M., et al. "Heritability and genetic correlations of milk production traits of first calving Holstein Frisian cow in Vojvodina". 23rd International Symposium "New Technologies in Contemporary Animal Production", Novi Sad. Proceedings, (2013): 47-49.

28. Kheirabadi K., et al. "Estimation of genetic parameters for daily milk yields of primiparous Iranian Holstein cows". Archiv fur Tierzucht 56 (2013): 44.

29. Samore AB., et al. "Genetic parameters for production traits and somatic cell scores estimated with a multiple trait random regression model in Italian Holsteins". Proceedings of the 7th WCGALP. 01-07, Montpellier, France (2002).

30. Vidovic V. "The Heritage of dairy properties at the level of production in the first lactation of cattle breeding" 44 (1987): 8587.

31. Weller JI., et al. "Effects of persistency and production on the genetic parameters of milk and fat yield in Israeli-Holsteins". Journal of Dairy Science 70 (1987): 672-680.

32. Van Vleck LD and Dong MC. "Genetic (co)variances for milk fat and protein yield in Holsteins using an animal model". Journal of Dairy Science 71 (1988) 3040-3046.

33. Jara A., et al. " (Co)variance components for lactation milk yield at three production and variability levels in Argentinean dairy cows". Proceedings of the 7th WCGALP Montpellier, France (2002).

34. Boldman KG and Freeman AE. "Adjustment for heterogeneity of variances by herd level in dairy cow and sire evaluation". Journal of Dairy Science 73 (1990): 503-512.

35. Meyer K. "WOMBAT - a tool for mixed model analyses in quantitative genetics by REML". Journal of Zhejiang University SCIENCE B 8 (2002): 815-821.

36. Petrovic MM., et al. "Result of the application on the technology of genetic improvement of Simmental cattle population in Serbia". Biotechnology in Animal Husbandry 22 (2006): 1-8.

37. Trifunovic G., et al. "The influence of certain paragletic factors on the characteristics of the dairy population of the black and white cows". Biotechnology in Animal Husbandry 18 (2002): 43-49.

38. Markovic BM. "Mixed Models-BLUP and animal model in estimation of the breeding value of the Holstein-Frisian race". PhD disorientation, Novi Sad (1996).

39. Trivunovic S. "Genetic trend of milk and dairy fat in the Exogenation of the Beech test for artificial ebmening". Doctor's thesis. Faculty of Agriculture, Novi Sad (2006). 
40. Vidovic V. "Coefficients of inheritance and correlation of more important dairy properties in the first two lactation of the cattle-breeding cows". Livestock (1986): 9-10.

41. Jovanovac Sonja. "A estimate of the cultivation of the Bulls Holstein-Friesa Pasmina in the conditions of Slavonia and Baranje". PhD disorientation. Ljubljana (1987).

42. Stojić P. "Factors of correction of the characteristics of dairy and their contributions evaluate the breeding values of bulls and cows". PhD discothethesis. Faculty of Agriculture, Belgrade (1996).

43. Mosharraf R., et al. "Estimation of (co)variance components and breeding values for test-day milk production traits of Holstein dairy cattle via Bayesian approach". Biotechnology in Animal Husbandry 30 (2014): 15-28.

44. Djurdjevic R and Vidovic V. "The assessment of genetic and phenotygenic parameters of the dairy of the Simental race". Modern farming. number three, Novi Sad (1994)

45. Swalve HH. "The Effect of Test Day Models on the Estimation of Genetic Parameters and Breeding Values for Dairy Cattle". Journal of Dairy Science 78 (1984): 741-971.

46. Naudin Hurtado-Lugo., et al. "Random regression models for milk, fat and protein in Colombian Buffaloes". Revsta MVZ Cordoba (online). 20 (2015): 4415-4426.

47. APW de Roos., et al. "Random regression Test-day Model in Netherlands". Interbull Bulletin 27 (2001): 155-158.

48. Jón Hjalti Eiríksson. "Test day model for Icelandic dairy cattle”. Agricultural University of Iceland (2017).

Volume 3 Issue 10 October 2019

(c) All rights are reserved by Snežana Trivunović., et al. 